\title{
The Laws on Tourism Promotion through Practice in Binh Duong Province
}

\author{
Nguyen Thu Cuc ${ }^{*}$ \\ ${ }^{1}$ Master's Degree, Major in Economic Law, Tra Vinh University, Tra Vinh, Viet Nam
}

DOI: $10.36348 /$ sijlcj.2021.v04i04.005

| Received: 11.03.2021 | Accepted: 15.04.2021 | Published: 21.04.2021

*Corresponding author: Nguyen Thu Cuc

\section{Abstract}

Tourism promotion activities have become an extremely effective tool to attract and persuade visitors to tourist destinations, which is a very essential factor in promoting tourism development. Therefore, tourism promotion is becoming a hot issue in tourism development in today's destinations. Because of the fact that in developed countries, tourism has been quite successful thanks to tourism promotion activities, contributing to the better development of the tourism industry. The promotion of tourism is considered as one of the key tasks of Vietnam's tourism in general and the tourism of provinces and cities in the country in particular. This study clearly shows the role and importance of tourism promotion law in promoting tourism development through the practice of Binh Duong province; from there, proposing solutions to improve this law.

Keywords: Laws, tourism promotion, practice, Binh Duong province, Vietnam.

Copyright ( $) 2021$ The Author(s): This is an open-access article distributed under the terms of the Creative Commons Attribution 4.0 International License (CC BY-NC 4.0) which permits unrestricted use, distribution, and reproduction in any medium for non-commercial use provided the original author and source are credited.

\section{INTRODUCTION}

Today, tourism is an indispensable human need in the modern world and has become one of the leading economic sectors of the world economy. For many countries, tourism is the most important source of foreign currency in foreign trade [1]. The World Travel and Tourism Council (2019) announced that tourism is the largest economic sector in the world, surpassing the automotive, steel, electronics, and agricultural industries. Tourism has become a global issue, many countries use the tourism criteria of residents as an indicator to assess the quality of life. According to the World Tourism Organization (2019), the number of international tourists worldwide will reach 1.6 billion by 2020 , of which East Asia - Pacific is the fastestgrowing region in the world at an annual rate of $6.5 \%$ for the period 1995-2020. This is an opportunity for Vietnam in general and Binh Duong province, in particular, to promote the tourism industry to thrive in a new period.

Binh Duong tourism has the greatest advantage of being large land, beautiful natural landscape, temperate climate, rivers, streams, and lakes. With many landscapes, many historical relics attract tourists from all over the world. On the other hand, because today's traffic is good, people from all other provinces and cities are very convenient to travel to Binh Duong province. Binh Duong province is also close to Tan Son
Nhat international airport, the future is Long Thanh international airport, close to seaports, etc. so it is very convenient for international tourists to Binh Duong province. Binh Duong province has 3 big rivers running through the area of Saigon province, Dong Nai province, and Binh Duong province, which helps cool air and green trees to develop easily. The fertile soil conditions are ideal for river tourism, riverside resorts, river entertainment such as boating, sightseeing yachts, swimming, water skiing, etc. Binh Duong province has many Hills, lakes, rivers, and streams that are the potentials for the development of tourism, which is very developed today, is close to nature, sightseeing, relaxing tourism, water sports, fishing, boating, etc. entertainment with nature such as Chau Thoi mountain (a national scenic spot), Nui Cau in the vast Dau famous lake, etc.

Binh Duong tourism also has many historical and cultural relics that have been ranked at the national level as the Southwest - Ben Cat Tunnel Area, Phu Loi Prison, Hoi Khanh Pagoda, etc. the Binh Duong province also has nearly 30 provincial-level monuments, more than 500 others monuments have not been ranked. Binh Duong was originally land in the South formed parallel to the city. Ho Chi Minh City, Dong Nai, there are many ancient cultural relics such as pagodas, communal houses, temples, old houses, ancient tombs, etc. that make tourists want to learn. 
Nguyen Thu Cuc., Sch Int J Law Crime Justice, Apr, 2021; 4(4): 219-226

However, the tourism industry in Binh Duong province still reveals many limitations: compared to other provinces, it is still low (keeping a quite far distance from some domestic provinces: in 2019, the number of international visitors to Binh Duong province) 4,750,000 arrivals, while Dong Nai 4,937,000 arrivals, HCMC 36,500,000 arrivals); the contribution of the tourism industry of Binh Duong province to the socio-economic development of Binh Duong province is not really superior to that of other industries; Infrastructure is outdated; the quality of tourism products and services has not yet met regional and international standards, etc. There are many reasons for the above situation (economic background, human factors, the impact of the global financial crisis, etc.), but there are direct causes from the framework. Current law System of legal documents on tourism promotion (Law on Tourism 2017 [2]; Decree No. 92/2007/ND-CP dated June 1, 2007, of the Government detailing the implementation of a number of articles of The Law on Tourism, is amended and supplemented by Decree No. 180/2013/ND-CP dated November 14, 2013, of the Government, amending and supplementing Decree No. 92/2007/ND-CP [3]; Decree No. 158/2013/ND-CP dated $12 / 11 / 2013$ of the Government stipulating sanctioning of administrative violations in the fields of culture, sports, tourism and advertising [4]; Circular No. $88 / 2008 /$ TT-BVHTTDL dated 30/12/2008 of the Ministry of Culture, Sports and Tourism guiding the implementation of Decree No. 92/2007/ND-CP dated June 1, 2007, of the Government detailing the implementation of a number of articles of the Law on Tourism on tourist accommodation, etc.) has become a useful tool for Binh Duong province to strengthen state management in the tourism sector.

However, after more than 3 years of implementation, 2017 [2] Tourism Law and its guiding documents also reveal certain limitations and shortcomings that need to be amended and supplemented: some contents in the 2017 Tourism Law It is not reasonable or some of the provisions in the Law are only estimates, not feasible, so they cannot be implemented; There are provisions in the Law on Tourism, after many years, there are still no guiding documents; there are many problems that have arisen in practice that has not yet been regulated by law; Besides, many legal regulations on tourism are not consistent with other relevant laws, etc. To a certain extent, the current legal provisions on tourism are both insufficient and redundant. The system is not high, making it difficult to implement, slow to come to life. This situation poses objective requirements in completing legal provisions on tourism promotion of Vietnam in general and Binh Duong province in particular.

\section{RESEARCH OBJECTIVES General Objective}

The general objective of the thesis is to analyze and evaluate the current legal status of tourism promotion in Binh Duong province, inadequacies, and causes, and clarify the emerging theoretical and practical issues. Since then, proposing solutions to perfect the law on tourism promotion in Binh Duong province

\section{SPECIFIC OBJECTIVES}

In order to achieve the above general objectives, the thesis implements the following specific objectives:

- The first is to clarify the rationale for completing the law in the tourism field.

- The second is to analyze, evaluate and explain the current legal status of tourism promotion in Binh Duong province.

- Thirdly, the thesis proposes a number of solutions to improve the law on tourism promotion in Binh Duong province.

\section{LITERATURE REVIEW}

Over the past years, in order to serve the professional work as well as the need to study and research a number of individuals and organizations working in the tourism field, there have been researching topics and dissertations. Topics related to this field, like:

Subject: "Development of tourism products based on the cultural values of ethnic groups in the Central Highlands". Head of the topic - Nguyen De, University of Culture, Ho Chi Minh City, ministry-level research, 1/2014 - 12/2015. The survey topic clarifies the cultural value potentials of ethnic groups in the Central Highlands, including tangible cultural values and intangible cultural values. Focusing on cultural values currently preserved by ethnic groups in order to exploit for tourism; Based on the cultural value potential of the ethnic groups in the Central Highlands, the topic will analyze and determine the direction to develop tourism products, and at the same time propose solutions to develop cultural tourism products in The cultural intersection context has been and is taking place as an inevitable and increasingly strong trend in the communities of the Central Highlands.

Topic "Solution to develop tourism brands in Vietnam". Project manager - Do Cam Tho, Tourism Development Research Institute, Ministry-level research project, January 2013 - December 2013. The theme Solution to develop Vietnam's tourism brand is a breakthrough topic assigned by the Minister of Culture, Sports, and Tourism to solve the goal: clarifying the scientific basis and proposing development solutions. Vietnam tourism brand meets the trend and development requirements of the tourism industry in the coming period.

The topic approaches a comprehensive research process from theory to practice, international comparison, applying methods and techniques in branding research, market research, and promotion. . 
Nguyen Thu Cuc., Sch Int J Law Crime Justice, Apr, 2021; 4(4): 219-226

The topic performed two-way analysis, on the one hand, assessing the status of product development, promotion, and promotion, the process of forming Vietnamese tourism brands at the national, regional, local and enterprise-level; on the other hand, research the market perception of Vietnamese tourism brands through the reference research results for many years and conducted 1,000 interviews, multi-object surveys including international tourists and domestic management, state management, businesses, communities to participate in tourism, from which to compare to find out brand awareness of the market. The research results are continuously compared with competing countries in the region to draw the core elements of the best recognized Vietnamese tourism brand. The topic also follows the development directions of the Strategy and Master Plan for tourism development in Vietnam to 2020, vision to 2030 to propose orientations and solutions to develop tourism brands.

Subject: "Research on responsible tourism activities in Vietnam". Project manager - Ha Van Sieu, Tourism Development Research Institute, Ministrylevel research project, January 2012 - December 2013. The study systematized the theoretical basis of responsible tourism: concepts, relationships, interests, behaviors between the parties participating in tourism activities, etc.; Specific experience of a number of tourist destinations in the world and in Vietnam: policy, organization, management, control, regulation, and evaluation mechanism, etc.; Current status of responsible tourism activities in Vietnam through field surveys: supply-side activities, demand-side activities, roles, responsibilities, and participation of all parties; Solutions to promoting responsible tourism.

Subject: "Current situation and some solutions to improve state management effectiveness in the tourism sector". Project manager - Nguyen Thi Bich Van, General Department of Tourism, 2001. Research has assessed the current state management effectiveness in the tourism sector and proposed some solutions to improve the effectiveness of state management in the tourism sector

Thesis: "Vietnam's marine tourism resources for resort tourism development". Mai Hien, Master's thesis in Tourism Studies, 2007. The thesis presented theories about the type of resort tourism; Presenting the composition, characteristics, and nature of marine resort tourism resources; List, evaluate the suitability and attractiveness of the basic types of resources in Vietnam's marine tourism resources, point out the area with many advantages in terms of natural resources, assess exploitation conditions Learn about the current status of exploitation and use of marine tourism resources to give directions to improve the efficiency of exploitation and sustainable use of natural resources, etc.

\section{RESEARCH RESULTS AND DISCUSSIONS Tourism promotion activities in Binh Duong province}

Visitors to Binh Duong province in recent years have strongly developed in both quantity and structure of tourists. The average growth rate of visitors in the period 2017 - 2019 reached $156.87 \%$ /year.

Table-1: Number of tourists coming to Binh Duong province (Source: Binh Duong Department of Culture, Sports and Tourism)

\begin{tabular}{|l|l|l|l|l|l|l|}
\hline \multirow{2}{*}{ Year } & Total & \multicolumn{2}{l|}{ Domestic visitors } & \multicolumn{2}{l|}{ International visitors } \\
\cline { 2 - 7 } & Amount & $\begin{array}{l}\text { Compared with the last year } \\
(\boldsymbol{\%})\end{array}$ & Amount & $\begin{array}{l}\text { Proportion } \\
(\boldsymbol{\%})\end{array}$ & $\begin{array}{l}\text { Amount } \\
\text { Proportion } \\
(\boldsymbol{\%})\end{array}$ \\
\hline $\mathbf{0 1 7}$ & 6.890 .601 & 127,12 & 4.500 .418 & 62.31 & 2.390 .183 & 34,69 \\
\hline $\mathbf{0 1 8}$ & 7.968 .970 & 115,64 & 4.529 .350 & 56,83 & 3.439 .620 & 43,17 \\
\hline $\mathbf{0 1 9}$ & 11.323 .080 & 227,87 & 6.573 .080 & 58,05 & 4.750 .000 & 41,95 \\
\hline
\end{tabular}

\section{International Tourists}

Binh Duong Provincial People's Committee has a plan to implement stimulus packages to attract international tourists, so the number of international tourists to Binh Duong province increases sharply in the period of 2017 - 2019. In 2017, it is 2,390. 183 guests, accounting for $34.69 \%$ [5], in 2018 increased to $3,439,620$ guests [6] and the highest increase was in 2019 with 4,750,000 visitors, equivalent to an increase of $38.09 \%$ compared to 2018 [7].

From the structure of international tourists to Binh Duong province, mainly Chinese, Russian, and Korean tourists, up to now, the tourist structure has become very rich and diverse with over 50 different nationalities. Chinese tourists come to Binh Duong province mainly for the purpose of visiting and shopping, while European tourists come from countries such as France, Germany, England, Sweden, etc. to Binh Duong province with the main purpose is to visit provincial landmarks that have unique humanitarian tourism resources

\section{Domestic Tourists:}

Domestic tourists to Binh Duong province mainly from Ho Chi Minh City and southern provinces for the purpose of visiting, resting, attending cultural festivals, service tourism, etc., in addition to a set the people of Binh Duong province also participated in the influx of weekend tourists.

From the data table can be seen, the number of domestic visitors to Binh Duong province gradually 
Nguyen Thu Cuc., Sch Int J Law Crime Justice, Apr, 2021; 4(4): 219-226

increases in the period of 2017 - 2019. The result is that Binh Duong province has organized many promotional activities such as festivals folk culture. Tourism businesses actively implement measures to stimulate tourism such as promotions and discounts. Especially, the long holidays have created conditions for visitors from the central, and Northern provinces to come to Binh Duong province.

As a result, although the number of international visitors decreased as the whole country, domestic tourists to Binh Duong province increased, contributing to the strong growth of domestic tourism in Binh Duong province in 2019 with 6,573,080 arrivals, an increase of $45.12 \%$ over the same period in 2018 [7]. Most domestic tourists come to Binh Duong province to enjoy the cool fresh air.

Thus, it can be seen that the number of tourists coming to Binh Duong province over the years has been irregular, international visitors to Binh Duong province are increasing with many different nationalities. The average guest stay in 2017 was 1.9 days; in 2018 it was 2.95 days; 2019 in 3.25 days [5-7].

\section{Law on tourism promotion}

Law is an objective social phenomenon, especially important but also extremely complicated, so from the past up to now, there have been many different conceptions and perceptions about the law. On the universal and most basic aspect and applying to contemporary socio-economic conditions, the legal definition can be stated as follows: "Law is a system of generally compulsory behavioral rules by the house. The country establishes or acknowledges, expresses the will of the state of the ruling class on the basis of recognizing the needs for the interests of the entire society, guaranteed to be performed by the state to adjust social relations for the purpose of social order and stability for the sustainable development of society" [8, p 288].

Law is a phenomenon of the superstructure, reflecting both socio-economic development level and guarantee value, promoting socio-economic development. Law is an important tool for the State to manage and regulate social relations. The state cannot exist without the law and vice versa the law can only bring into play its effectiveness and efficiency if it is guaranteed by the power of the state apparatus. manifested in the form of a law imposed by the government, otherwise, the two hours of will is just air vibrations caused by empty sounds" [9, p 51]. Therefore, the law always shows the will of the class holding the power of the state.

In a socialist rule of law state, the law is an instrument for social development. Our State is a state of the people, by the people, for the people, the law must belong to the people, by the people, for the people.
The law is the basis for building "civil society" and is an indispensable value in the rule of law state. The document of the Ninth National Congress of the Party affirmed: "Our State is the main tool to exercise the people's mastery, the rule of law of the people, by the people and for the people. State power is unified, with assignment and coordination among state agencies in the exercise of legislative, executive and judicial powers. The State manages the society by law" [10, pp. 131,132]. Document of the Tenth National Congress of the Party also affirmed: "Our State is a socialist rule-oflaw state exercise the legislative, executive, and judicial powers. Completing the legal system, increasing the specificity and feasibility of provisions in legal documents, etc." [11, p. 125]. Document of the 11th National Congress of Delegates continues to affirm: "Continue to promote the building and perfecting of the socialist rule of law state, ensuring that our State is true of the people, by the people for the people and for the people, led by the Party, etc. Improve the State's management and governance capacity according to the law, strengthen the socialist legislation" [12, p 126].

Since the implementation of "Innovation" up to now, the Party and the State of Vietnam have always considered the continuous improvement of the legal system a great, regular and important concern of the country. This is reflected in most of the Party's documents, especially the Resolution of the 8th Central Conference (Session VII), the Resolution of the 8th National Party Congress, the Resolution of the Ninth National Party Congress, Resolution of the Xth National Party Congress, Resolution of the XI National Party Congress, Resolution No. 48 - NQ/TW of the Politburo dated May 24, 2005, etc.

Implementing the policy of building a socialist rule-of-law state of the Party, the National Assembly, the Government, and state agencies in charge of tourism have been making efforts to fully develop legislation in the tourism sector and efficiency. However, it should be emphasized that the current system of legal documents in the tourism sector is both lacking, redundant, unspecific, and systematic, and its impact on the implementation process is still limited institutions need to be revised, supplemented, and improved.

On the theoretical basis, so far there is no unified definition of the tourism promotion law. However, the legal norm in the tourism sector, like other legal regulations, is generally compulsory, is a template for all subjects to comply and is an assessment criterion of human behavior issued or recognized by the competent authority and applied many times in life until it is changed or canceled. Another point is that the legal norm in the tourism sector only regulates social relations arising in the process of organizing and operating tourism.

Thus, the law in the tourism sector is a system of legal regulations promulgated or recognized by the 
Nguyen Thu Cuc., Sch Int J Law Crime Justice, Apr, 2021; 4(4): 219-226

State and implemented to regulate social relations arising in the process of organizing and operating tourism. calendar, including the provisions of tourism resources; tourism development planning; tourist area, tourist destination, tourist route, and tourist urban area; tourists; Business Travel; Tour guide; tourism promotion; international cooperation on tourism; tourism inspection, handling requests and recommendations of tourists.

\section{The current situation of law application on tourism promotion in Binh Duong province in recent years}

In recent years, Binh Duong province has issued many legal documents on tourism promotion in the province, specifically:

Decision No. 2303/QD-UBND “On approving the tourism development planning of Binh Duong province to 2025 , with a vision to 2030" issued on August 15, 2011. With the aim of:

To build tourism into an economic branch with an important position in the economic structure, contributing to the process of economic restructuring of the province; at the same time, it is a tool to improve the quality of people's lives, to meet the needs of rest and enjoy the spirit of the local people.

Effectively exploit the advantages of geographical location and tourism potential to form branded tourism products with local cultural characteristics.

Tourism development, using revenues from tourism activities to contribute to the conservation and efficient exploitation of historical relics, cultural heritage values, ecological environmental values, ensuring development sustainable in both tourism and ecological environment.

\section{Orientation planning south space:}

The spatial scale in the South includes the area of Thu Dau Mot Town, Thuan An Town, Di An Town, and a part of Ben Cat District:

Main tourism products include: Ecotourism (garden tourism, river tourism), cultural tourism (visiting cultural-historical sites, festivals, craft villages, spiritual tourism, and beliefs), entertainment, weekend travel, vacation travel, shopping travel, MICE travel, and highend sports tourism;

Priority areas for investment: Areas along the edge of Lai Thieu garden (Thuan An town), areas along Saigon River (in Ben Cat district). Development Center: Thu Dau Mot Town service tourism.

\section{Orientation of spatial planning in the Northwest:}

Space in the Northwest includes the area of Dau Tieng lake, Cau mountain, Saigon river corridor, and the vicinity of Dau Tieng district and Ben Cat district;

Main tourism products include: resort tourism, cultural tourism, ecotourism, high-class sports tourism;

Areas of investment priority: Area of Dau Tieng lake, area along Saigon river, area of Can Nom lake. Development center: Dau Tieng town service and tourism.

\section{Orientation of space planning in the East:}

The spatial scale in the East includes the area along the basin of Dong Nai and Be rivers in Tan Uyen District, Phu Giao District;

Main tourism products include Ecotourism with types of river eco-tourism, resort tourism, weekend tourism, and high-class sports tourism.

Plan No. 3088/KH-UBND on the implementation of the program "Vietnamese to travel to Vietnam" in Binh Duong province, issued on June 29, 2020, by the People's Committee of Binh Duong province.

Accordingly, the Department of Culture, Sports and Tourism coordinates with departments, sectors, tourism associations, People's Committees of districts, towns, cities, and tourism service businesses to launch the program. "Vietnamese traveling to Vietnam" on media and communication channels. Promote tourism communication on the media, widely information about the safety level, ready to attract tourists; at the same time guide regulations on ensuring safety for tourism activities, tourists, workers, and local communities. Announcement on the exemption of entrance fees at the province's historic and scenic destinations to travel businesses, tourists inside and outside the province Mobilize and encourage tourismrelated businesses in the province to participate; guide, monitor, and urge businesses to seriously implement promotional commitments when participating in the "Vietnamese traveling to Vietnam" program to ensure a safe, friendly and quality tourism environment. Along with that, implementing the tourism demand stimulus program, focusing on exploiting the domestic market including tourists within the province and other provinces (Hanoi, Ho Chi Minh City, and Southeastern and Delta Mekong River provinces) from June to the end of December 2020 in the whole province.

The Department of Culture, Sports and Tourism coordinates with business units of tourism services, traditional craft villages in the province to organize and participate in promoting Binh Duong tourism on events taking place inside and outside the province during the period next time: 60th Anniversary Vietnam Tourism Day (July 9, 1960 - July 9, 2020), The 3rd Binh Duong Food Festival 2020, International 
Nguyen Thu Cuc., Sch Int J Law Crime Justice, Apr, 2021; 4(4): 219-226

Tourism Fair ITE-HCM 2020, Can Tho National Amateurs Festival 2020, and other events.

Draft plan 'Implementing Vietnam's tourism development strategy to 2030 in the province of Binh Duong" dated November 6, 2020. The Provincial People's Committee has just issued a plan to implement the Vietnam tourism development strategy until 2030 in the province of Binh Duong.

The Provincial People's Committee requested a plan to implement the Vietnam tourism development strategy to 2030 in the province in a synchronous manner, with the initiative and coordination of departments, functional agencies, and the People's Committees of districts, towns and cities to support and facilitate the rapid and sustainable development of the tourism sector in the coming time.

The target is set in the period of 2021-2025, striving to increase the average number of visitors to visit and stay by about $15 \% / y e a r$ or more; Revenue from tourism is about $20 \%$ year or more. By 2025 , to attract tourists to visit and stay about 5,250,000 visitors (of which international visitors are about 320,000); revenue from tourism is about 2,090 billion VND; training, retraining, and professional training in tourism and skills related to tourism activities for about 400-500 turns of people; proposing the establishment of a tourism development fund to support training, propaganda, tourism promotion, and tourism product development.

In the period of 2026-2030, strive for an average growth rate of about $7 \%$ /year of visitors coming to visit and stay; Revenue from tourism increases about $12 \%$ / year. By 2030, attract tourists to visit and stay about 8,100,000 visitors (of which about 480,000 international visitors); revenue from tourism is about 3,700 billion $\mathrm{VND}$; training, retraining, and professional training in tourism and skills related to tourism activities for about 600-700 turns of participants $[7,8]$.

Decision 1877/QD-UBND dated 1-8-2013 of the Provincial People's Committee on approving the Project of propaganda, promotion and promotion of tourism in Binh Duong province for the period of 20132015, orientation to 2020 and Decision No. 1878/QDUBND dated August 1, 2013, of the Provincial People's Committee approving the Project to develop Binh Duong specific tourism products to 2015 , with a vision to 2020, the Provincial Tourism Promotion Center is implementing activities to develop tourism in the province in the right direction.

In recent years, in addition to tourist sites in the province, new types and programs have been built to serve the needs of tourists for sightseeing, entertainment, and relaxation, promotion, and promotion. Tourism of the provincial tourism promotion center also contributes to promoting and introducing Binh Duong tourism and bringing tourists to Binh Duong. Mr. Nguyen Duc Minh, Director of the provincial tourism promotion center, said that Binh Duong tourism website (dulichbinhduong.Org.vn) is one of the advertising channels of Binh Duong tourism that has brought into full play and created favorable conditions event for tourists to find out information about Binh Duong tourism in recent years. In 2018, the website received more than 150,000 visitors looking for travel information; since the website was put into operation, there have been more than 458,000 visitors.

\section{Proposing perfecting the law on tourism promotion}

Currently, tourism activities in Vietnam are adjusted according to the provisions of the 2017 Tourism Law and the guiding document system, in addition, there are many contents on tourism management scattered in many documents. other laws: Law on Cultural Heritage in 2001 and Law amending and supplementing a number of articles of Law on cultural heritage in 2009; Law on Natural Resources and Environment Protection 2014; Law on Export Tax and Import Tax 2016; Law on Road Traffic 2008; Enterprise Law 2014, etc.; Decree No. 57/2015/ND-CP dated June 16, 2015, of the Government, amending and supplementing a number of articles of the Government's Decree No. 152/2013/ND-CP dated November 4, 2013, on the management of motor vehicles brought in by foreigners in Vietnam, etc. However, in general, the legal system of tourism promotion in our country still lacks comprehensiveness, is incomplete and synchronous inconsistency in some areas, even contradictions, low feasibility, slow to come to life. Facing the impact of changes in social relations and leading to the implementation of the Law on Tourism and documents detailing the implementation of the Law on Tourism still has many shortcomings and problems. These shortcomings and problems cannot be completely resolved in the detailed implementing regulations because the original regulations in the Law on Tourism are inadequate and inappropriate, so the rules in the detailed regulations, execution instruction cannot go beyond the original code.

Thus, to a certain extent, the current legal provisions on tourism can be said to be both insufficient and redundant, and the system is not high, so it can cause certain difficulties for the implementation. Regulations on specific sectors need to be amended and supplemented for tourism to develop as a key economic sector.

Faced with that situation, on June 9, 2015, the National Assembly of the Socialist Republic of Vietnam issued Resolution No. 89/2015/QH13 regulating the Law/Ordinance formulation program for the term of the National Assembly term XIII, 2015 and the 2016 Law and Ordinance Construction Program. 
Nguyen Thu Cuc., Sch Int J Law Crime Justice, Apr, 2021; 4(4): 219-226

This Resolution has approved the amendment and supplementation of the Law on Tourism at the 2nd session of the 14th National Assembly (scheduled for October 2016). Amending and supplementing the 2005 Tourism Law, the 2017 Tourism Law and the guiding documents system will contribute to the complete legal system in the tourism sector, creating a synchronous, unified innovation is suitable not only in content but also in form with basic requirements: legal documents of the state must be issued in accordance with competence, form, order, and procedures; ensure the hierarchy of legal documents; both synchronous with domestic law, and consistent with international law qualifications and practices.

One of the important contents of the 2017 Tourism Law [2] is the regulation: The travel business does not need to have legal capital but must deposit a deposit to ensure responsibility for tourists.

According to Article 16 of Decree $168 / 2017 /$ ND-CP on the management and use of the deposit, the purpose of the deposit is: "In case a tourist dies, has an accident, risks, harming the life and needing to bring to the residence or urgent treatment but the enterprise is unable to arrange the funds for timely settlement, the enterprise shall send a request for temporary clearance of the deposit to the issuing authority travel service business license. Within 48 hours from the time of receiving the request of the enterprise, the agency granting the travel service business license shall consider and request the bank to allow the enterprise to deduct the deposit account to use or refuse".

Thus, it can be seen that "deposit" is to solve the problems of tourists when facing risks. Specifically, the fund is only used when visitors are killed, have an accident, risk, or have had their life compromised and need to be taken back to the residence or for urgent treatment. This purpose seems to be "overlapped" with regulations on compulsory insurance in the Vietnamese legal system:

First, the travel service business is the construction, sale, and implementation of a part of the whole tourism program for guests. A travel program is a document showing the itinerary, services, and prices that are predetermined for a tourist's trip from the origin to the end of the trip. Therefore, using passenger transportation will be an indispensable part of most trips. According to the Law on Insurance Business, motor vehicle owners and airline carriers are required to purchase civil liability insurance for passengers. The law also stipulates that the inland waterway transport operator must purchase the vehicle owner's civil liability insurance for the passengers and the third person, the passenger carrier by sea, is obliged to buy liability insurance the carrier's civil liability for the passenger. In addition, the Law on Tourism also stipulates that organizations and individuals doing tourist transport business must buy insurance for tourists by means of transport. Thus, when transporting tourists, owners of means of transport must buy insurance for tourists.

Second, in addition to the insurance purchased by the carrier, the tourist can also be reimbursed for medical treatment, or even the costs of death, by health insurance. The Law on Health Insurance stipulates that health insurance is a form of compulsory insurance that is applied to subjects in accordance with the Law. Although the beneficiaries of health insurance have been greatly expanded, in addition to workers, students, students, etc. (even foreigners studying in Vietnam are granted scholarships. from the budget of the State of Vietnam), however, it still does not cover all the scope of tourists. But it can be seen that the majority of tourists who are Vietnamese when having an accident, health and life-related risks will be covered by health insurance.

Third, the Law on Tourism also stipulates that the travel business must buy insurance for tourists during the travel program unless the tourist already has insurance for the entire tour program. . The insurance company will pay the cost of the loss of health, property, and luggage for people living in Vietnam (including those of Vietnamese nationality and foreign nationals living in Vietnam) want to travel, visit, and work or study abroad at home as well as abroad.

Thus, in Vietnam, with these three types of insurance, the payment for risks, accidents, or loss of health and life for visitors can be made in a timely manner. In which, we believe that selling insurance to tourists is the most important. Because, in order for insurance companies to sell their products, they will have to inspect and validate the product supply process, so they will closely monitor and monitor the activities of the businesses where they sell their products. . Unreasonable acts and activities may be excluded by insurance companies. No insurance company continues to sell or impose low premiums on businesses that do poorly or keep incidents.

In addition, according to the provisions of Article 16 of Decree 168/2017/ND-CP, the fund is only used in case tourists die, have an accident, risk, or have their life compromised but the business does not the ability to arrange to fund for timely settlement, the need to bring to residence or urgent treatment but the enterprise is unable to arrange the fees for timely settlement. Intangible, this rule has pushed risks for tourists. State regulators really need to reconsider this issue. Because travel business is a profession that faces many risks such as natural disasters, traffic accidents, climbing accidents, waterfall climbing, food poisoning, etc. If a travel business if you do not have enough money to pay and solve problems for customers, you 
should not let these businesses exist. Although Vietnam is mobilizing all resources for tourism development, but not developing tourism at all "prices", leading to the interests of tourists is not guaranteed. Recently, the mass media has reflected that some Vietnamese travel companies have even accepted 0 VND tour visitors [8]; Due to its small scale, low management costs lower tour prices; providing poor quality products that cause unfair competition; deceiving tourists, causing discretion, affecting the national tourism brand, etc. Therefore, businesses that cannot afford the financial capacity need to be excluded from the market.

\section{CONCLUSION}

Tourism and law in the tourism sector is a complex issue, directly and indirectly, related to many aspects of social life, related to the system of state management agencies from the central to local levels. , businesses and people. After 60 years of establishment and development, the system of legal documents in the tourism field has been promulgated by a relatively large number of state agencies, of which the 2017 Tourism Law has been implemented for 3 years reveals many problems and shortcomings and has many contents that cannot come to life.

Therefore, in order to further promote the construction and completion of the law, create a favorable legal framework for tourism to develop commensurate with the position and role of the "key economic sector", it is required by law. In the tourism sector, appropriate adjustments must be made. On the other hand, in order to continue the cause of building a Socialist State of Vietnam in general and Binh Duong province in particular in the period of accelerating industrialization - modernization and the context of deeper international integration and broadly, the issue of perfecting the legal system in general and perfecting the law in the tourism sector, in particular, is necessary to meet the requirements of social life, serving the country's renovation.

\section{REFERENCE}

1. World Tourism Organization. (2013), Tourism Knowledge: Basic Terms. Hanoi: The World.

2. Congress. (2017). The Tourism Laws. Hanoi.

3. Goverment. (2007). Decree No. 92/2007/ND-CP dated June 1, 2007 of the Government detailing the implementation of a number of articles of the Law on Tourism as amended and supplemented by Decree No. 180/2013/ND-CP dated June 1, 2007. November 14, 2013 of the Government amending and supplementing the Decree No. 92/2007/ND-CP.

4. Government. (2013). Decree No. 158/2013/ND$\mathrm{CP}$ dated 12/11/2013 of the Government stipulating sanctioning of administrative violations in the fields of culture, sports, tourism and advertising.

5. Department of Culture, Sports and Tourism. (2018). Tourism Statistics Report 2017.

6. Department of Culture, Sports and Tourism. (2019). Tourism Statistics Report 2018.

7. Department of Culture, Sports and Tourism. (2020). Tourism Statistics Report 2019.

8. Congress. (2005). The Tourism Law. Hanoi

9. Lan, D. T. (2015). Vietnam Tourism Integration and Development in the New Period, Vietnam Tourism Development Workshop in the New Period. Hanoi.

10. Sieu, H. V. (2013). Research responsible tourism in Vietnam. Tourism Development Research Institute, Ministry-level research project.

11. The National Council directed the compilation of Vietnamese Encyclopedia. (2006). Vietnamese Encyclopedia, Volume 1. Hanoi: The Encyclopedia.

12. Tuan, L. N. (2009). State management of tourist accommodation establishments in Vietnam in the trend of integration. Master Thesis in Tourism. 